\title{
Assessment for Learning: Turkey Case
}

\author{
Ismail San \\ Faculty of Education, Inonu University, Turkey
}

Copyright (C) 2016 by authors, all rights reserved. Authors agree that this article remains permanently open access under the terms of the Creative Commons Attribution License 4.0 International License

\begin{abstract}
Why do we test students? To label them or teach them better? Labeling students is one of the most common errors of educators. If we don't want to fall into that error, then we should use those scores more useful. Marking pupils and focusing on the next examination is not the right approach for humanitarian systems. Then, what should we do? Constructivist approach claims that all activities should focus on learning. Thus, assessing students can be seen as opportunity to enhance learning. Using assessment for learning enhances students' motivation and academic success, decreases the anxiety for examinations. Especially, the countries, that use central examinations to promote students to higher education steps, should see assessment activities for a learning opportunity.
\end{abstract}

Keywords Assessment, Learning, Testing Effect, Motivation

\section{Introduction}

Caine \& Caine [1], argued that learning is to be increased via encourage and decreased via thread. Also, focusing to the learning material makes to learn the topic easier. In case of lacking a dimension for focusing, each detail related to the topic is thought as important as one another. Focusing to some dimensions of a topic not only reduces the unit to a manageable size but also provides a selective criterion for understanding and orientation for interpreting what was read.

Clarity of expectations is the first stage in a learning process. Thus, putting foreground the content that is aimed to gain is important and organizing the variables that are not connected to it primarily. Underlying clearly and obviously the expected behavior during the learning process of pupils, makes learning/teaching easier due to focusing to the learning content and materials.

\subsection{Testing Effect}

In case of including the right questions, examinations are informative tools about which behaviors should be focused on [2]. By testing, in other words using of any form of instrumentation, not just tests a person's knowledge level; it also affects that level. This effect is called as "testing effect".

Shadis, Cook \& Campbell [3] says that, "sometimes taking a test once will influence scores when test is taken again... for example, weighing someone may cause the person to try lose weight when they otherwise might not have done so, or taking a vocabulary pretest may cause someone to look up a novel word and so perform better at posttest (pp: $60)$... They also descripted the effects as "effects due to repeated testing of participants over time (pp: 512). This definition underlies the fact that experiences change our schemes. Thus, it can be summarized as: the more interaction with the key concepts the more learning the content.

It is pointed out at the studies that investigate the factors affecting the success of test ([4], [5], [6], [7], [8], [9], [10]) and the causes of failure ([11], [12], [13]) motivation affects the success and low-motivation causes failure.

\subsection{Motivation for Learning}

To make pupils willing to learn, in other words increasing their motivation is important to realize learning. "Motivation is an internal state that arouses pupils to action, directs them to certain behaviors, and assists them in maintaining this action and direction with regard to behaviors important and appropriate to the learning environment" [14]. Motivation, an internal situation, has for key dimensions for consideration: interest, relevance, expectancy, and satisfaction. These dimensions are directly related to understanding and motivating a classroom.

In case of academic needs are met, motivation and academic achievement are enhanced. [15] listed the twelve academic needs of pupils that are primarily related to classroom motivation and academic achievement, as following:

Pupils have a need to:

1. understand and value learning goals,

2. understand the learning process,

3. be actively involved in the learning process,

4. have learning goals related to their own interests and choices,

5. receive instruction matched to their learning styles and strengths,

6. see learning modeled by adults as an exciting and rewarding process,

7. experience success,

8. have time to integrate learning,

9. receive realistic and immediate feedback that enhances self-efficacy, 
10. be involved in self-evaluating their learning and effort,

11. receive appropriate rewards for performance gains, and

12. experience a supportive, safe, well-managed learning environment.

The increasing motivation of pupils causes some affects on their learning. Ormrod [16] listed these affects as following:

Motivation:

1. directs behavior toward particular goals.

2. increases effort and energy in pursuit of these goals.

3. increases initiation of and persistence in certain activities, even in the face of occasional interruptions and frustrations.

4. affects, cognitive processes, such as what learners pay attention to and how much they think about and elaborate on it.

5. determines which consequences are and aren't reinforcing and punishing.

As stated by Ormond [16], motivation can be used as a tool for focusing learning materials and content. There is a link between "equilibration" [17] and "motivation" concepts. Piaget [17] believed that during children's cognitive development, they strives to come to a balance between applying previous knowledge (assimilation) and changing behavior to account for new knowledge (accommodation). This balance, called equilibration by Piaget [17], helps explain how children are able to move from one stage of thought into the next. Considering the fact that pupils perform learning easier to come to a balance [18] suggests that motivation affects cognitive structure. So it can be argued certain level of imbalance can be used to motivate pupils to the topic [14].

There are two kinds of motivation: intrinsic and extrinsic. Intrinsic motivation is motivation to become involved in an activity for its own sake. Extrinsic motivation is motivation to become involved in an activity as a means to an end [19]. Intrinsically motivated students take part in their learning due to they see the task is funny and/or important. They don't engage in that activities for a concrete rewards or incentives, but because they see the activities themselves rewarding and pleasurable.

\section{Examinations}

It is known that environmental situations are effective about activating intrinsic motivation [20]. The activities that motivate intrinsically need to be challenging [21]. Challenging activity has partially hard targets and the success of it is not guaranteed at the start of process. Using these activities to design courses, help to enhance the intrinsic motivation of classroom [20].

Examinations are challenging activities for pupils and therewithal success is not guaranteed. Thus, examinations can be used to create intrinsic motivation and to enhance learning levels of pupils [22], [14].

Scheerens, Glas \& Thomas [23] described examinations as following:

Examinations are sets of learning tasks or test items and specific procedures to administer these (e.g. written and oral exams, portfolio's showing samples of accomplishments). These are used to determine whether a candidate has the required level of achievement to be formally certified as having successfully completed a program of formal schooling or training.

Examinations are used for different goals. These goals are shown on a schema by Tekin [24] as following.

Ways to collect data, in other words examination, can be used for teaching.

The main purpose to use teaching tests is to enhance teaching. This kind of examinations are arranged to make students be able to see their strengths and weaknesses, to highlight important points and to reinforce the favorable behaviors. Test results are evaluated by either students or teacher and the sheets are given back to students for whole class discussion. This discussion helps to remember the answers that students forgot during examination, to become aware of and to fix their wrong answers. Discussing the test results, extremely effective learning experience, prepares a deeper and wider learning environment [24].

The ultimate purpose of assessment and evaluation activities is not to grade pupils. If these activities were used to identify the lack of pupils' learning, to enhance the learning level and to route them vocational-personal; they would be used for learning [25].

\section{Studies on Assessment for Learning}

Crossman [26] says that "the less you use a piece of information, the further back in your memory your brain will stuff it, and it may take quite a bit of effort to pull it out again". This quote implies that if the teaching process was clear, comprehensible and being away from unnecessary details, the retention would be enhanced. Examinations, due to giving an idea about what to focus on, it will very likely to facilitate pulling knowledge out again. This viewpoint can be seen at Socrates, too. Socrates asked some questions to pupils instead of directly inform them.

Questions are used to make pupils experience an effective learning. The questions that are in text-books and workbooks at the end of a unit help pupils learn the topic [27].

In generally, the benefits of questions that have convenient features and asked appropriately are listed by Açıkgöz [27] as following: 


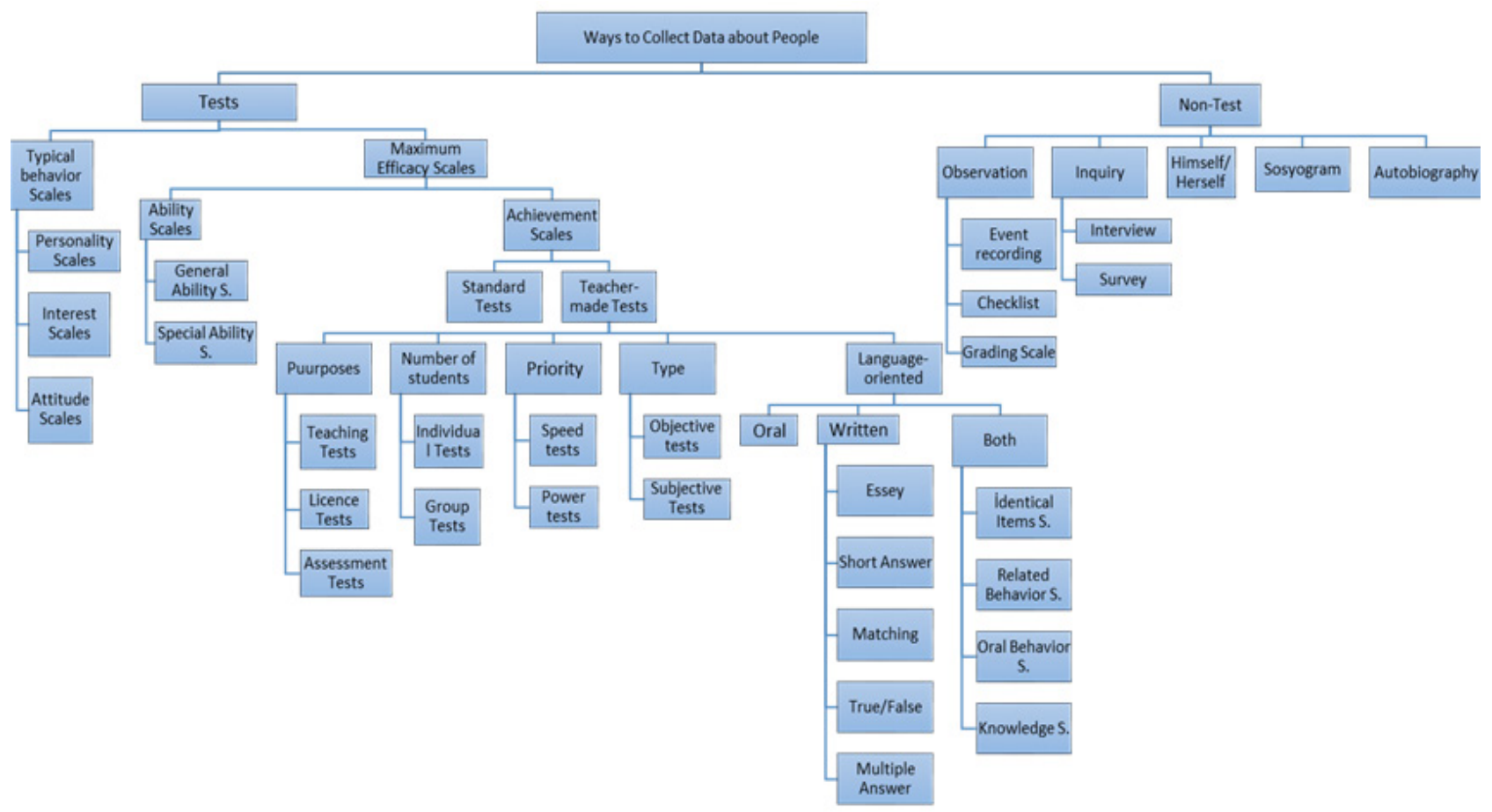

Figure 1. Ways to collect data about people (adapted from Tekin [24])

a) Asking or answering questions directs pupils to think and activate mentally.

b) Questions can be used to attract and promote pupils,

c) The answer that are given to questions by pupils, inform teachers about pupils' level, development rate and direction. So, we can help pupils on determining and restocking what they need.

d) It provides speaking and writing opportunity to pupils.

e) Asking and answering questions usually enhance pupils academic achievement.

Using questions for teaching paves the way for using examinations for the same purpose. Irons [22] states that formative assessment is not just evaluation it also gives shape to pupils, in other words provides learning. Şevik [28] says that, the core of pupils-teacher communication is constituted by questions, and a good teacher must be a good inquirer. He also suggests that if the right questions are asked in right time by teacher will help to use course period more effectively. Cowie, Moreland \& Otrel-Cass [29] suggest that teaching would be more productive in case of using assessment for learning, in their 15-year-old study. They states that, in-course-learning should be assessed. By assessment for learning (AfL) pupils thought themselves as learner and cognizant person. Thus, pupils contribute classroom interactions. Similarly Rohrer \& Pashler [30] states that placing examinations on teaching process provides benefits to learn and retention.

Walvoord \& Anderson [31] states that tests can be used for teaching. The study also suggests that the more effective assessment the more learning. Irons [22] says that giving feed-back to pupils is one of the important roles of teachers. He puts forward that assessment and evaluation affects pupils' intrinsic and extrinsic motivation. Thus they help pupils to learn topic. According to Walvoord \& Anderson [31], the key points of learning process and teacher-pupils communication are the quality and timing of feed-backs. In this context, they suggest that formative assessment enhance learning. Also, they assert that formative assessment was important for instruction process due to it provides application opportunity for self-evaluation. It can be predicted that formative assessment and feed-backs are beneficial more than the other studying processes that don't contain any reward for participation.

Frankland [32] says that teaching and learning can be enhanced via evaluation, and evaluation has deep effects on pupils' learning. He also suggests that the ways pupils to learn are determined by evaluation types. In that context, he puts forward organizing and performing evaluation activities could help us to understand the ways to enhance teaching-learning process quality.

According to Boud \& Falchikov [33], evaluation is quite valuable for the debates that are about standards, vocational training, quality measurement and motivation. For this reason, he suggests that evaluation should be used in learning process.

Stiggins, Arter, Chappius \& Chappius [34] focuses in-class-evaluation for pupils learning. They say assessing learning was not enough for teachers, pupils and parents, and suggest that "assessment for learning" had effects on pupils' motivation.

Lee [35] underlines that evaluation could be used to teach mathematics. He means AfL as a learning process that are shaped by evidence of pupils' learning. According to him, higher quality evidences about what pupils understand, do or know provide more opportunity to form pupils' future learning. 
Lambert \& Lines [36] says that if evaluation activities are appropriate then they affect teacher and pupils. The study, defines formative assessment as "...the information gathered is used to enhance the learning potential of the pupils" and assessment should focus on learning and teaching. It is stated in this study that grading pupils is not the fundamental purpose of assessment. If formative assessment is done correctly, enhances pupils' learning motivation, shows what they need to learn, and provides learning and assessing to learn. They categorize approaches to learning in three groups as surface, deep and strategic. According to them, a student's learning approach is effected by assessment process.

Topbaş \& Yücel-Toy [37] states that examinations can be used for teaching. Examination, no matter the type or purpose, has three components: (1) examiner, (2) examinee and (3) examination topic. Examinations, making to focus examiner and examinee on a topic, give information about examinee adhering to the topic. An examination consists of three stages: (1) before, (2) process, and (3) after.

Examiner is engaged in examination before it to prepare, during it to ensure compliance of conditions and after it to review test results. By the way the examinee prepares for examination before it, seeks solutions to questions during it and investigates the accuracy of the answers after it [37].

When pupils are observed during midterm and final periods, it can be seen that they study very hard before and during examination. After examination they discuss the questions asked in examination. Pupils are in interaction with examination topic actively at all three periods. An activity (examination), that is so successful to make pupils interacting with topic, can be used for teaching and learning process, too. On the other hand, when we consider that all teaching activities were result by an examination and an assessment via [37], then we can infer that using examination as a learning method would be useful for examinee.

The purpose is not to use as mid-term and final examinations for grading pupils in teaching process but to apply regularly for helping them on effective learning as a learning tool. Otherwise, mid-term and final examinations applied once in a term cause pupils to study heavily. Studies in cognitive psychology show that studying with breaks and in small periods contributes to learning and retention more than studying heavily with no break [38], [39].

Thus, present studies emphasis on applying examinations as a learning tool frequently and regularly instead of the purpose that intends to grade pupils [40]. For example the study by Kang, McDermot \& Roediger [41] on graduate students indicates that short-answer tests with feed-back provide long term retention. So, the study suggests using short-answer test with feed-backs regularly to teach effectively.

Learning-centered assessment approach, that intends to enhance learning via focusing pupils and what they learn, should be involved in the teaching process [42], [43]. In the environments that include teaching and assessment together, it is stated that pupils has opportunity to apply what they learn and also to get feed-back, thus they could assess and enhance their own performance [43]. In fact, one of the goals of in-class assessment that intends to teach pupils, is to be able to create the regular cycle of feed-back that provide information about both pupils' learning and teacher's teaching deficiencies [44]. It is because; feed-backs waken instructor up about the goals reached or hadn't reached yet with the reasons.

Also, it is emphasized [45] that fixing the deficiencies and mistakes, hence monitoring formative assessment were important to prepare appropriate learning environment for creating accurate schemes. Owing to frequently assessment and feed-backs given on time makes possible to remove deficiencies in no time, to resolve the confusion, to think while they are learning about what and how they learn, to develop learning strategies and study habits, to interact more with teacher and pupils, to increase motivation hence effective learning and retention [22], [46].

Experimental studies [41], [46], [47], [48], [49], show that retention of learning units could be enhanced via testing. Memory tests not only measure the learning level but also affect it [50], [51].

Examinations, when they are used in teaching process, enhance pupils' motivation and retention rate. Considering the academic success is proportional to recall speed, it can be suggested that using examinations at teaching process could enhance pupils' academic performance.

According to Vygotsky [52], the psychological process of a person doesn't develop independently of sociological process. The fact that there had been social processes at the beginning of psychological processes like learning and motivation points out that there was a relationship between the rates of students' expectation met of secondary level and promoting system to secondary education.

\section{Why Assessment for Learning: Turkey case}

The score gained from TEOG (Transition from Primary to Secondary Education) exam and the type of high-school registered has great effects on career choice. Compared to OECD countries, Turkey is the top on the academic success inequality league [53]. Considering the success rates of high-schools types in Turkey, it can be claimed that success on TEOG is seen equivalent to insuring entrance to university [54]. Success difference between school types can be observed from the PISA-2012, YGS-2013, LYS-2013 scores.

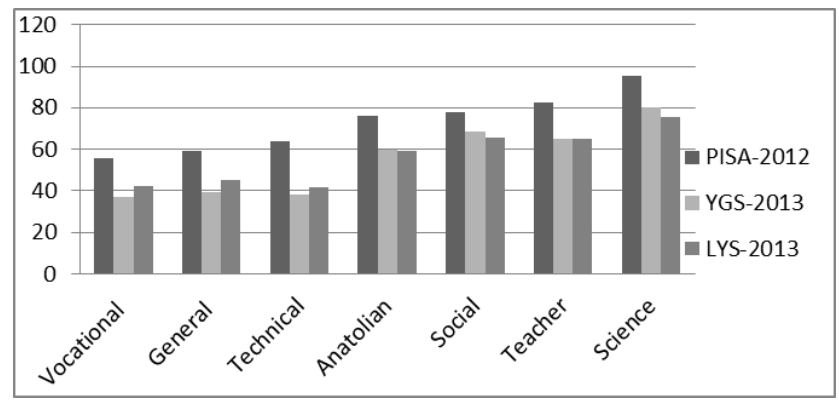

Figure 2. Comparing the high-school types in Turkey 
Analyzing PISA-2012 (mathematical literacy) [55], YGS-2013 [56] and LYS-2013 [57] results shows that Science and Anatolian types are more successful than other types. This may because teachers and students of this school types are selected via examinations. A parent that is aware of this reality cares TEOG score extremely. However, the pupil preparing to enter to adolescence should keep up with the problems due to changing physical appearance [45]. To be able to get high-scores on TEOG is needed to develop cognitive development. Development on both physical and cognitive domains is not companion with the principle of development of any domain follows a sequential pattern. Thus, the conclusion about revoking the entrance exams for high school [58] is one of the underlying decisions of XVIIth National Education Council.

High corelation between TEOG score and YGS-LYS scores [59] causes pupils to conditioning for TEOG exam success. This conditioning results with tending to non-school institutions.

In Turkey, one of the functions of school education is "...eliminating the negative effects and reinforcing the positive effects of environment..." [60]. Pupils tending to non-school institutions show that schools aren't efficient about to realize this duty. Pupils are not satisfied with teaching process in schools due to unsuitability for TEOG [61], [62]. According to students, school teaching is not enough for being successful at TEOG [63]. This situation also effects teachers and teaching process.

According to students and parents, central exam scores (in this study TEOG) are the principal criteria for being respectable and successful in Turkish society [64]. There were 1.406 .182 applicants for 7.328 civil servant positions in KPSS-2012 (a central exam for staff officer selection that is applied biennially) [65]. Economic turmoil in Turkish economy caused heavy conditions for self-employed people and private employees [66]. Thus people in Turkey tend to be civil servant and central exam success has been more important than ever.

Pupils' desire for exam-oriented study is one of the barriers that prevents teacher to apply constructivism [67].

\section{Results and Conclusions}

Although focusing to examinations is not desired, assessment for learning could be the cement for enforcing the link between pupils and school. Output of a learning process is also the determinant of input [26]. Thus, the output of a learning process is important.

There are a few learning-teaching methods that use examinations during teaching process. Examinations are being used as diagnosing (diagnostic), formatting (formative) and deciding (summative) goals. Learning-Through Exam, Mastery Learning and Programmed Learning Methods employ examinations during teaching process.

\section{REFERENCES}

[1] Caine, R.N. \& Caine, G. (1994). Making connections: Teaching and the human brain. Menlo Park, California: Addison Wesley Pub. Co.

[2] Fraenkel, J. R. \& Walen, N. E. (2005). How to design and evaluate research in education (6. bask1). New York: McGraw Hill.

[3] Shadis, W. R., Cook, T. D. \& Campbell, D. T. (2002). Experimental and quasi-experimental designs for generalized causal inference. Boston: Houghton Mifflin Company.

[4] Anthony, G. (2010). Factors influencing first-year students' sucess in mathematics. International Journal of Mathematical Education Science and Technology, 31 (1), 3-14. http://dx.doi.org/10.1080/002073900287336.

[5] Davis-Kean, P. E. (2005). The influence of parent education and family income on child achievement: The Indirect role of parental expectations and the home environment. Journal of Family Psychology, 19 (2), 294-304.

[6] Ferguson, E., James, D. \& Madeley, L. (2002). Factors associated with success in medical school: systematic review of the literatüre. Learning in Practice, 324, 952- 957.

[7] Frischenschlager, O., Haidinger, G. \& Mitterauer, L. (2005). Factors associated with academic success at Vienna Medical School: Prospective Survey, 46 (1), 58-65. http://neuron.mefst.hr/docs/CMJ/issues/2005/46/1/15726677 .pdf.

[8] Vaglum, P., Wiers-Jenssen, J. \& Ekeberg, O. (1999). Motivation for medical school: the relationship to gender and speciality preferences in a nationwide sample. Medical Education, 33, 236-242.

[9] Volery, T. \& Lord, D. (2000). Critical success factors in online education. The International Journal of Educational Management, 14 (5), 216-223.

[10] Weymer, R. A. (2002). Factors affecting students' performance in sith grade modular technology education. Journal of Technology Education, 13 (2), 34-47. http://scholar.lib.vt.edu/ejournals/JTE/v13n2/pdf/weymer.pd f.

[11] Akbaba-Altun, S. (2009). An investigation of teachers', parents', and students' opinions on elementary students' academic failure. Elementary Education Online, 8 (2), 567-586.

[12] Baumard, P. \& Starbuck, W. H. (2005). Learning from failures: Why it may not happen. Long Range Planning, 38, 281-298.

[13] Maier, S. F., Albin, R. W. \& Testa, T. J. (1973). Failure to learn to escape in rats previously exposed inescapable shock depends on nature of escape response. Journal of Comparative and Physiological Psychology, 85 (3), 581-592.

[14] Wiseman, D. G. \& Hunt, G. H. (2013). Best practice in motivation and management in the classroom (3. Bask1). Springfield: Charles C Thomas Publisher.

[15] Jones, V. \& Jones, L. (2013). Comprehensive classroom management: Creating communities of support and solving problems (10. Bask1.). Boston: Pearson K.

[16] Ormrod, J. E. (2011). Human learning (6th ed.). Boston: 
Pearson.

[17] Piaget, J. (1973). The psychology of intelligence. Tototwa, N. J.: Littlefield, Adams.

[18] Berk, L. (2010). Development through the lifespan (5.bask1). Boston: Allyn \& Bacon/Pearson.

[19] Anderman, E., \& Anderman, L. (2010). Motivating children and adolescents in schools. Columbus, $\mathrm{OH}$ : Merrill/Prentice-Hall.

[20] Akbaba, S. (2006). Eğitimde motivasyon. Kazım Karabekir Eğitim Fakültesi Dergisi, 13, 343-361.

[21] Deci, E. L. \& Ryan, R. M. (1985). Intrinsic motivation and determination in human behavior. New York: Plenum Press.

[22] Irons, A. (2008). Enhancing learning through formative assessment and feedback. London: Routledge.

[23] Scheerens, J., Glas, C., \& Thomas, S. M. (2003). Educational evaluation, assessment and monitoring. A Systemic approach. Lisse, Swets\& Zeitlinger Publishers.

[24] Tekin, H. (1993). Ĕgitimde ölçme ve değerlendirme. Yarg1 Yayınları, Ankara.

[25] Bahar, M. Nartgün, Z., Durmuş, S. \& Bıçak, B. (2010). Ölçme ve değerlendirme teknikleri (4.Bask1). Ankara: Pegem Akademi.

[26] Crossman, A. (2011). Study smart, study less. Berkeley: Ten Speed Press

[27] Açıkgöz, K.Ü. (2011). Aktif öğrenme. İzmir: Kanyılmaz Matbaas1.

[28] Şevik, M. (2005). Yabanci dil öğretiminde sorular, öğrenci cevaplari ve öğretmen davranişlari, Ankara Üniversitesi Eğitim Bilimleri Fakültesi Dergisi Cilt 38 (Say1 2) 1-19.

[29] Cowie, B., Moreland, J. \& Otrel-Cass, K. (2012). Expanding notions of assessment for learning. Rotterdam/Boston/Taipei: Sense Publishers

[30] Rohrer, D. \& Pashler, H. (2010). Recent research on human learning challenges conventional instructional strategies. Educational Researcher, 39 (5), 406-412.

[31] Walvoord, B.E. \& Anderson, V.J. (2010). Effective grading: A tool for learning and assessment in college (2.bask1). San Francisco: Jossey-Bass.

[32] Frankland, S. (2007). Enhancing teaching and learning through assessment. Dordrecht: Springer.

[33] Boud, D. \& Falchikov, N. (2007). Rethinking assessment in higher education: Learning for the longer term. London/New York: Routledge.

[34] Stiggins, R. J., Arter, J. A., Chappuis, J. \& Chappuis, S. (2007). Classroom assessment for student learning. Doing it right-using it well.

[35] Lee, C. (2006). Language for learning mathematics: Assesment for learning in practice. Berkshire: Open University Press.

[36] Lambert, D. \& Lines, D. (2001). Understanding assessment: Purposes, perceptions, practice. London/ New York: RoutledgeFalmer
[37] Topbaş, E. \& Yücel-Toy, B. (2010). Öğretmen adaylarının sınav yoluyla öğrenme yöntemine ilişkin görüşleri. Hacettepe Üniversitesi Eğitim Fakültesi Dergisi, 44, 287-299.

[38] Donovan, J. J. \& Radosevich, D. J. (1999). A meta-analytic review of the distribution of practice effect: Now you see it, now you don't. Journal of Applied Psychology, 84 (5), 795805

[39] Myers, C. B. \& Myers, S. M. (2007). Assessing assessment: The effects of two exam formats on course achievement and evaluation. Innovative Higher Education, 31(4), 227-236.

[40] Butler, A. C. \& Roediger, H. L. (2007). Testing improves long-term retention in a simulated classroom setting. European Journal of Cognitive Psychology, 19 (4/5), 514-527

[41] Kang, S. H. K., McDermott, K. B. \& Reodiger, H.L. (2007). Test format and corrective feedback modify the effect of testing on long-term retention. European Journal of Cognitive Psychology, 19 (4/5), 528-558.

[42] Gerdy, K.B.(2002). Teacher, coach, cheerleader, and judge: Promoting learning through learner-centered assessment. Law library journal, 94 (1), 59-88

[43] Huba, M. E. \& Freed, J. E. (2000). Learner-centered assessment on college campuses: Shifting the focus from teaching to learning. Boston, MA: Allyn \& Bacon.

[44] Yao, Y. \& Grady, M.L. (2005). How do faculty make formative use of student evaluation feedback?: A multiple case study. Journal of Personnel Evaluation in Education, 18 (2), 107-126.

[45] Senemoğlu, N. (2004). Gelişim, öğrenme ve öğretim: Kuramdan uygulamaya. (9. Bask1). Ankara: Gazi Kitabevi

[46] Tinto, V. (2010) From theory to action: Exploring the institutional conditions for student retention. J.C.Smart (Ed.), Higher education: Handbook of theory and research, Volume 25 (pp.51-90). New York: Springer.

[47] Erdelyi, M. H. \& Becker, J. (1974). Hypermnesia for pictures: Incremental memory for pictures but not words in multiple recall trials. Cognitive Psychology, 6, 159-171.

[48] Erdelyi, M. H., Finkelstein, S., Herrel, N., Miller, B. \& Thomas, J.(1976). Coding modality vs. input modality in hypermnesia: Is a rose a rose a rose? Cognition, 4, 311-319.

[49] Srivastava, D.S. \& Kumari, S. (2005). Education: Assessment, evaluation and remedial. India: Isha Books.

[50] Lachman, R. \& Laughery, K. R. (1968). Is a test trial a training trial in free recall learning? [Abstract]. Journal of Experimental Psychology, 76.

[51] Tulving, E. (1967). The effects of presentation and recall of material in free-recall learning. Journal of Verbal Learning Verbal Behavior. 6, 175-184.

[52] Vygotsky, L. S. (1978). Mind in society. M. Gle, V. J. Steiner, S. Scribner \& E. Souberman (Eds). Cambridge, Mass: Harward University Press.

[53] OECD (2013). OECD skills outlook 2013: First results from the survey of adult skills (summary in Turkish). 25.02.2014 tarihinde OECD.

[54] Gür, B. S., Çelik, Z. \& Coşkun, İ. (2013). Türkiye'de ortaöğretimin geleceği: Hiyerarşi mi eşitlik mi? SETA. 
[55] MEB (2013). PISA 2012 ulusal ön raporu. Yenilik ve Eğitim Teknolojileri Genel Müdürlüğü, Ankara.

[56] ÖSYM (2014). 2013-Yükseköğretime geçiş sınavının (2013-YGS) değerlendirilmesi. 08.02.2014 tarihinde http://dokuman.osym.gov.tr/pdfdokuman/2013/OSYS/2013YGS-SonucAciklama_Sunum.pdf adresinden alındı.

[57] ÖSYM (2014a). 2013-Lisans yerleştirme sınavları (2013-LYS) sonuçlar1. 08.02.2014 tarihinde http://www.osym.gov.tr/dosya/1-69292/h/2013-lyssayisalbil gilerbasin.pdf adresinden alınd.

[58] MEB-TTKB (2006). XVII. Milli Eğitim Şûrası Kararları. Ankara: MEB.

[59] Bahar, M. (2009). Ortaöğretim kurumları sınavı'na gore anadolu ve fen liselerine yerleştirilen öğrencilerin OKS ve ÖSS sonuçları arasındaki ilişki. Yayımlanmamış Doktora Tezi. İstanbul Üniversitesi Sosyal Bilimler Enstitüsü.

[60] Balcı, A. (2010). Açıklamalı eğitim yönetimi terimleri sözlüğü (2. Bask1). Ankara: Pegem Akademi.

[61] Budak, M. \& Okur, M. (2012). 2005 ilköğretim matematik dersi 6-8.sınıflar öğretim programına ilişkin öğretmen görüssleri. International Journal of New Trends in Arts, Sports \& Science Education, 1 (4).

[62] Çakıroğlu, E. (2013). Matematik öğretim programı tanıtımı.
Eğitim Bilişm Ağı (EBA). 25.12.2013 tarihinde http://www.eba.gov.tr/video/izle/5403788fece7e0cb342ac8e e67276d42fcdd381ed6002 adresinden alınmıştır.

[63] Çevik, E. (2009). İlköğretim II. kademe sosyal bilgiler dersi ögretmenlerinin yazılı sınav soruları ile seviye belirleme sınavi sorularının programa uygunluğunun incelenmesi. Yüksek Lisans Tezi, Niğde Üniversitesi, Sosyal Bilimler Enstitüsü.

[64] Türk, E. (2007). Ailenin sosyo-ekonomik ve demografik özellikleri ile mezun olunan okul ve özel dershanenin öğrencilerin kontrol odakları, akademik tutumları ve ortaöğretime giriş sınavındaki başarıları üzerindeki etkileri. Yüksek Lisans Tezi, Van: Yüzüncü Y1l Üniversitesi Sosyal Bilimler Enstitüsü.

[65] ÖSYM (2014b). KPSS-2012/2 Yerleştirme sonuçlarına ilişkin sayisal bilgiler. 08.02.2014 tarihinde http://www.osym.gov.tr/dosya/1-61105/h/kpss20122yerlestir mesayisalbilgiler.pdf adresinden alındı.

[66] Albayrak, C. (2012). Küreselleşme ve ekonomik krizin iş hukukuna etkisi. Türkiye Barolar Birliği Dergisi, 98, 165-202.

[67] Ayvac1, H. Ş. \& Nas, S. E. (2009). Fen ve teknoloji dersi konularının okulda ve dershanede işlenişiyle ilgili durumların belirlenmesi. Dicle Üniversitesi Ziya Gökalp Eğitim Fakültesi Dergisi, 13 (2009), 113-124. 